\title{
Production of Solid Fuel by Torrefaction Using Coconut Leaves as Renewable Biomass
}

\author{
L.D.B. Pestañoa, ${ }^{\mathrm{a}}{ }^{*}$ and W.I. Jose ${ }^{\mathrm{b}}$ \\ aUniversity of Santo Tomas, Department of Chemical Engineering, España, Manila 1008, Philippines \\ ${ }^{b}$ University of the Philippines, National Graduate School of Engineering, Department of Chemical Engineering, Diliman, Quezon City 1101, Philippines
}

\begin{abstract}
The reserves of non-renewable energy sources such as coal, crude oil and natural gas are not limitless, they gradually get exhausted and their price continually increases. In the last four decades, researchers have been focusing on alternate fuel resources to meet the ever increasing energy demand and to avoid dependence on crude oil (Karunanithy et al. 2012). Amongst different sources of renewable energy, biomass residues hold special promise due to their inherent capability to store solar energy and amenability to subsequent conversion to convenient solid, liquid and gaseous fuels. At present, among the coconut farm wastes such as husks, shell, coir dust and coconut leaves, the latter is considered the most grossly under-utilized by in situ burning in the coconut farm as means of disposal. In order to utilize dried coconut leaves and to improve its biomass properties, this research attempts to produce solid fuel by torrefaction using dried coconut leaves for use as alternative source of energy that can be utilized in the indirect drying of coconut meat in the farm-level to produce copra. Torrefaction is a thermal method for the conversion of biomass operating in the low temperature range of $200^{\circ} \mathrm{C}-300^{\circ} \mathrm{C}$ under atmospheric conditions in absence of oxygen. Dried coconut leaves were torrefied at different feedstock conditions. The key torrefaction products were collected and analyzed. Physical and combustion characteristics of both torrefied and untorrefied biomass were investigated. Torrefaction of dried coconut leaves significantly improved the heating value compared to that of the untreated biomass. Proximate compositions of the torrefied biomass also improved and were comparable to coal. The distribution of the products of torrefaction depends highly on the process conditions such as torrefaction temperature and residence time. Physical and combustion characteristics of torrefied biomass were superior making it more suitable for fuel applications.
\end{abstract}

Keywords: Torrefaction, biomass, coconut leaves, renewable energy

Article History: Received June 24th 2016; Received in revised form August $16^{\text {th }}$ 2016; Accepted 27th 2016; Available online

How to Cite This Article: Pestaño, L.D.B. and Jose, W.I. (2016) Production of Solid Fuel by Torrefaction Using Coconut Leaves As Renewable Biomass. Int. Journal of Renewable Energy Development, 5(3), 187-197.

http://dx.doi.org/10.14710/ijred.5.3187-197

\section{Introduction}

The more comfortable human life is paid by excessive energy increase in all its forms. The reserves of non-renewable energy sources (coal, crude oil, natural gas) are not limitless, they gradually get exhausted and their price continually increases. Nevertheless, they cover about four fifth of the energy consumption (Brožek et al., 2012).

In the last four decades, researchers have been focusing on alternate fuel resources to meet the ever increasing energy demand and to avoid dependence on crude oil (Karunanithy, 2012).
Amongst different sources of renewable energy, biomass residues hold special promise due to their inherent capability to store solar energy and amenability to subsequent conversion to convenient solid, liquid and gaseous fuels. Further, it is the only renewable source of carbon and a host of other chemicals. Recovery of chemical and industrial grade carbon for chemicals and explosives and value added amorphous silica from rice husk, a suitable reinforcing filler in plastic and rubber moulding, are a few typical examples.

With world-wide shortage of wood, especially in developing countries, and need for reforestation to

${ }^{*}$ Corresponding Author: +632-9178667496; fax: +6327314041

Email: lbpestano@ust.edu.ph 
maintain global ecological balance, increasing demand is being made for proper utilisation of agro and forestry biomass residues to play the role hitherto carried out by wood. Development of technologies, such as torrefaction to utilize this major resource and their management need to be emphasised to meet the demands of domestic as well as industrial sectors.

Torrefaction is a new technology which can improve biomass properties for a higher quality and more attractive biofuel. The main principle of torrefaction from a chemical point of view is the removal of oxygen with a final solid product: the torrefied biomass which has a lower $0 / C$ ratio compared to the original biomass.

At present, among the coconut farm wastes such as husks, shell, coir dust and coconut leaves, the latter is considered either the most grossly under-utilized or completely un-utilized by in situ burning in the coconut farm as means of disposal. In order to utilize dried coconut leaves in the coconut farm and to improve its biomass properties, this study aims to determine the possibility of producing solid fuel by torrefaction using dried coconut leaves for use as alternative source of energy that can be utilized in the indirect drying of coconut meat in the farm-level to produce copra. The effects of torrefaction temperature and holding time on the torrefaction of coconut will be examined.

\subsection{Biomass}

Biomass as energy source shows some typical characteristics which make it special, but rather complicated fuel for the future (Van der Stelt et al., 2011). Biomass resources include various natural and derived materials, such as woody and herbaceous species, wood wastes, bagasse, agricultural and industrial residues, waste paper, municipal solid wastes, sawdust, biosolids, grass, waste from food processing, animal wastes, aquatic plants and algae etc. Woody materials are preferred above food crops because they contain much more energy. Another characteristic of biomass is its climate neutral behaviour. If biomass is grown in a sustainable way, its production and application produces no net amount of $\mathrm{CO}_{2}$ in the atmosphere. The $\mathrm{CO}_{2}$ released by the application of biomass is stored in the biomass resource during photosynthesis which means a climate neutral carbon cycle of $\mathrm{CO}_{2}$. Biomass is considered to be environmentally friendly alternative to fossil fuels because it is naturally produced by photosynthesis from $\mathrm{CO}_{2}$ and $\mathrm{H}_{2} \mathrm{O}$ (Davis et al., 2009).

On the other hand, some biomass properties are inconvenient, particularly its high oxygen content, a low calorific value, a hydrophilic nature, high moisture content, degradation during storage and low energy density of raw lignocellulosic biomass. Also, the energy production from biomass resources shows reduced overall energy efficiency due to photosynthesis. The overall energy efficiency from solar energy to biomass energy is $1-3 \%$ (Herman, 2006). The high amount of oxygen also results in smoking during combustion. Other disadvantages of biomass are its tenacious and fibrous structure and its heterogeneous composition that makes process design and process control more complicated.

The use of biomass is also subjected to limitation of land, water and competition with food production. The agricultural production of biomass is relatively land intensive and involves high logistics costs due to low energy density of biomass. For biomass based systems a key challenge is to develop efficient conversion technology which can also compete with fossil fuels.

\subsection{Thermal conversion processes}

Burning biomass in an oxidative environment is the oldest conversion process practiced by man. Combustion, however, does not intend to produce value-added products in the form of fuels, chemicals or materials, as other thermochemical conversion technologies, but only heat energy (Basu, 2010).

Thermochemical biomass conversion technology represents the process of exposing organic material to elevated temperatures under an oxygen depleted atmosphere. The aim of such a process is to thermally break down lignocellulosic material into smaller compounds that can be utilized directly or more easily upgraded into value-added products.

Thermal conversion processes can be categorized into combustion, gasification, pyrolysis and the emerging torrefaction technology according to the operating conditions. The products of the thermochemical processes are divided into a volatile fraction consisting of gases, vapors and tar components and a carbon rich solid residue.

\subsubsection{Direct Combustion}

Direct combustion of biomass to take advantage of its heating value has been known for ages, but the process is not favoured anymore because biomass has very high moisture content to perform stable combustion. Thus, it has highly changeable combustion rates. On the other hand, the density for many kinds of biomass is lower than that of coal, leading to important economic limitations in transportation. In order to overcome these problems, briquetting of low density biomass species before combustion has been considered. Furthermore, it is also possible to mix biomass with coal in various proportions and then produce coal-biomass briquettes.

The total volatile matter content of the briquettes (biobriquette) is proportional to its biomass content. Biomass in the biobriquette makes ignitability easy and increases the burning rate of low grade coals. In general, combustion proceeds in two stages in which the volatile matter mainly evolved and burned to lead 
the fixed carbon combustion. From this point of view, biomass acts a promoter in combustion (Lu et al., 1997).

Mechanically strong briquettes may be obtained if the briquetting pressure and the time applied during the combustion operation are adjusted properly. However, combustion of biobriquettes having very high mechanical strength leads to an undesirable case during combustion due to limited diffusion of oxygen into the very compact structure. Firm briquettes cannot be obtained if subjected to under pressure below optimum value. Negative effects on the mechanical strength result to application of excessively high pressure (Yaman et al., 2001, Yaman et al., 2000).

\subsubsection{Pyrolysis}

Pyrolysis has been used for producing charcoal for the past 38,000 years for a wide variety of uses, such as heating, cooking, art-making, metallurgy, chemical industry, purification, soil amelioration, and medicine. Pyrolysis is a thermochemical conversion of biological material into solid (char), liquid (pyrolysis/bio-oil), and permanents gases, in the absence of $\mathrm{O}_{2}$ producing high liquid yields at elevated temperatures $\left(400-500^{\circ} \mathrm{C}\right)$, vapor residence time less than $5 \mathrm{~s}$, and an apparent heating rate of $10-200^{\circ} \mathrm{C}$ (Balat et al., 2009; Bridgewater, 2012; Zhang et al., 2007). The pyrolysis process consists of a very complex set of reactions involving the formation of radicals.

Fast pyrolysis has been developed relatively lately. It is different from traditional pyrolysis where charcoal is product of interest, mainly because it is aimed to produce liquid fuel that can be used as a substitute for crude oil. It utilizes high heating rates and short vapor reactor residence time. Bio-oil cannot be utilized directly in internal combustion engines and thus has to be upgraded in order to be used as a replacement for gasoline or diesel fuel (Ciolkoz and Wallace, 2011; Antal and Gronli, 2003; Bell and Worall, 2011; Rousset et al., 2011; Mohan et al., 2006).

Primary decomposition of biomass material $\left(<400^{\circ} \mathrm{C}\right)$ consists of a degradation process, whereas the secondary thermolysis $\left(>400^{\circ} \mathrm{C}\right)$ involves an aromatization process (Fisher et al., 2002).

\subsubsection{Gasification}

Among various thermo-chemical conversion methods gasification is the most promising (Van der Stelt et al., 2011). Gasification is the partial oxidation of carbonaceous feedstock above $800^{\circ} \mathrm{C}$ to produce a syngas that can be used for many applications such as gas turbines, engines, fuel cells, producing methanol and hydrocarbons. Due to its higher efficiency, it is desirable that gasification becomes increasingly applied in future rather than direct combustion (Prins et al., 2006, 2006, 2005). Linking gasification with power systems increases the efficient use of thermal energy streams.
The gasification of biomass is a thermal treatment, which results in a high proportion of gaseous products and small quantities of char (solid product) and ash. If the purpose is to maximize the liquid product yield, process conditions are selected at low temperature, high heating rate and short gas residence time. For high char yield, low temperature and low heating rate are required. In order to produce high yield of gas product, high temperature, low heating rate and long gas residence time should be applied (Demirbas, 2001).

\subsection{Review of torrefaction technology}

Torrefaction is a new technology to upgrade biomass for combustion and gasification applications. It is a thermal pre-treatment technology carried out at atmospheric pressure in the absence of oxygen. Torrefaction of biomass can be described as a mild form of pyrolysis that occurs at temperatures between 200 and $300^{\circ} \mathrm{C}$ where a solid uniform product is produced. This product has a very low moisture content, high calorific value (Ustu et al., 2008) and less hydrophilic compared to the untreated biomass to fresh biomass (Brožek et al., 2012). Furthermore, the fibrous and tenacious nature of the biomass is reduced, resulting in a brittle material that can easily be comminuted into smaller particles (Van der Stelt et al., 2011).

\subsubsection{Torrefaction technology concepts}

The majority of the torrefaction technologies being developed are based on already existing reactor concepts designed for other purposes such as drying or pyrolysis (Kiel, 2011), and thus only require technical advancement for torrefaction applications. Most torrefaction technology developers have extensive backgrounds in biomass processing and conversion technology, such as carbonization and drying. Currently, no single technique is fundamentally superior to the others as all of them have their advantages and disadvantages (Beekes and Cremers, 2012; Melin, 2011; Kleinschmidt, 2011). Therefore, for given biomass properties and application, the proper technology can be selected.

\subsubsection{Torrefaction reactors}

The reactors being developed are in most cases established technologies that developers are familiar with and have been optimizing for torrefaction applications. Proper selection of reactor is important as each reactor has unique characteristics and is well suited to handle to specific type of biomass (Dhungana, 2011; Ciolkosz and Wallace, 2011).

\subsubsection{The auger reactor}

The first and only commercial torrefaction reactor, employed in the Pechiny process in 1980's (France) was an auger reactor. It consisted of a horizontal shell and 
concentrically placed auger. The heat was supplied to the process by conduction through both the shell and auger via thermal oil. Thus, this was an indirectly heated reactor. The biomass plug flow through the reactor was maintained by the auger. The reactor had accurate temperature control due to limited heat transfer, but it required a long residence time (60-90 min). Free-flowing material was necessary for this reactor to operate properly. The biomass fill ratio for this type of reactor was 60-70\% (Bergman et al., 2005).

\subsubsection{Rotary drum}

A rotating drum reactor design was experimentally tested for torrefaction by Bergman et.al. (2005). This technology is relatively simple and employs a rotating cylinder with metal bars along its circumference to help tumble the biomass. The rotating drum reactor can be heated directly and indirectly. In the directly heated reactor heating medium, usually nitrogen is in a direct contact with biomass. However, in the indirectly heated system heat is supplied to the biomass through the reactor wall. A directly heated reactor has good heat transfer characteristics due to the permanent mixing of biomass; however, directly heated reactor performs worse than the auger reactor due to lower heat transfer coefficient and longer solids residence time. Its fill ratio is only about $10-15 \%$, which significantly decreases the reactor throughput.

\subsubsection{Moving bed reactor}

A moving bed reactor may be vertical or horizontal. Its advantage is simple, compact design and high fill ratio $(100 \%)$. It can also be directly or indirectly heated. In the former case, very high heat transfer coefficients can be achieved, which translates into short residence times. A pressure drop in vertical reactor can be significant. Non-free flowing biomass can be processed in this type of reactor (Bergman et al., 2005).

\subsubsection{Fluidized bed reactor}

A fluidized bed reactor has been widely used in the thermochemical conversion of biomass feedstock, such as pyrolysis, gasification, and combustion. In these reactors the fluidizing medium (usually gas) is passed through a bed of solid, granular, inert material (sand) at high velocity, causing the solid to behave as a fluid. The advantages of this technology are the high heating rate and heat transfer coefficient, as well as the stable and uniform temperature due to the vigorous mixing, large surface area, and thermal mass of the heat carrier. Nonetheless, attrition of sand particles makes it hard to separate torrefied biomass from sand, which can increase ash content. Moreover, biomass can be hard to fluidize due to its irregular shape (Li et al., 2012).

\subsubsection{Microwave}

Microwave radiation is electromagnetic radiation in the frequency range $0.3-300 \mathrm{GHz}$. Specialized "microwave chemistry" reactors utilize radiation whose frequency is $2.4 \mathrm{GHz}$. The same frequency can be used to thermally process biomass. This frequency forces polar molecules of biomass to oscillate at the resonant frequency and induces friction and heating. Since the heating is generated in the entire volume of biomass at once, this phenomenon is known as a volumetric heating. The advantage of microwave torrefaction is the uniform biomass heating, shorter heating time, small footprint, and accurate control (Budarin et al., 2011; Ren et al., 2010).

\subsubsection{Production technology}

Torrefaction is the thermal upgrading (heating) of biomass into an energy-dense and homogeneous product useful for further thermochemical conversions (Yan et al., 2010). Torrefied biomass retains up to $96 \%$ of its chemical energy, becomes hydrophobic and resistant to biodegradation. Furthermore, biomass loses its visco-plastic properties, becomes brittle and can grind easily (Van Essendelft et al., 2013; Rousset et al., 2013). Torrefaction is carried out in an inert environment (typically nitrogen) and normally under atmospheric conditions (Ben and Regauskas, 2012; Kim et al., 2012; Rousset et al., 2013; Chen et al., 2011) although some groups are experimenting with torrefaction under pressure (Wannapeera and Worasuwannarak, 2012) and in oxygenated environment (Rousset et al., 2012; Lu et al., 2012) as well as in hot compressed water (so-called wet torrefaction) (et al., 2009). During torrefaction, the more easily combustible components of biomass (i.e. hemicelluloses) are decomposed first and most vigorously, through carbonization and devitalisation. Only minor decomposition of lignin and cellulose occur at torrefaction temperatures $\left(200^{\circ} \mathrm{C}-300^{\circ} \mathrm{C}\right)$ but rate of decomposition depends on the type of biomass (Almeida et al., 2010). Their chemical structure is changed but no significant mass losses occurs (Bergman, 2005; Tumuluru et al., 2010).

\subsubsection{Torrefaction product distribution and composition}

Key torrefaction reaction products (of which the solid is of main interest) can be classified according to their state at atmospheric pressure and room temperature (Prins et al., 2006). These include solids (in the form of char, original sugar structures and ash) and all the volatile compounds released during the process. The volatiles consist of condensables or liquids (mainly water, organics and lipids) and noncondensables or the permanently gaseous fraction (mainly $\mathrm{CO}$ and $\mathrm{CO}_{2}$ ) (Kiel et al., 2012; Tumuluru et al., 2010; Chen et al., 2012). See Figure 1. The distribution 
of these products depends highly on the process conditions such as torrefaction temperature and residence time (Schorr et al., 2012; Chen et al., 2012).

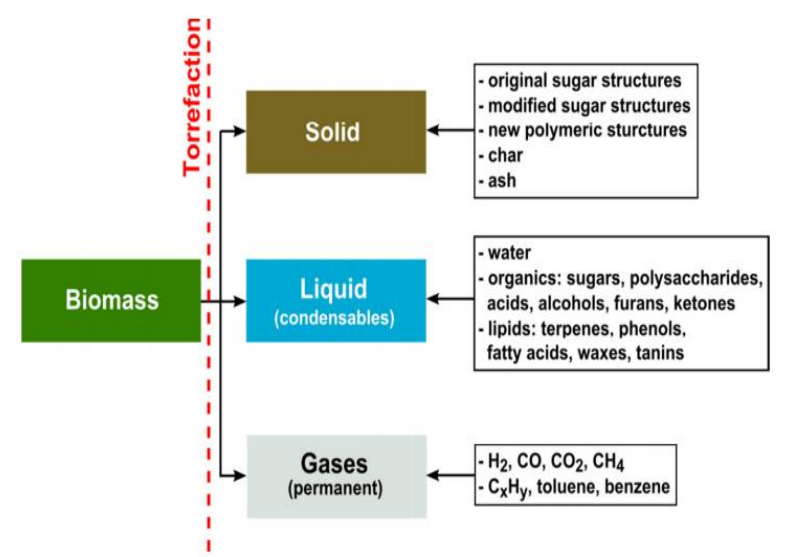

Fig. 1 Composition of the torrefaction reaction products (Bergman et al., 2005)

\subsection{Coconut palm as a renewable source of energy}

In these days of energy shortage, the worth of the coconut palm as energy source deserves consideration. Sugar cane, cassava, forest trees and oil bearing plants have all been carefully considered as possible sources of calories.

\subsubsection{The coconut palm}

The coconut palm (Cocos nucifera L.) is one of the principal crops of many Pacific Islands and a vital basis of their economics. A peculiarity of this palm is the regular monthly production of a bunch of nuts that consists of a kernel in a hard wooden shell surrounded by a thick fibrous husk. The palm frond has several leaves arranged along a hard wood midrib or petiole.

The coconut has its own good points. It is a permanent crop. Once planted there is no need to reprepare the land with consequent expenditure of energy. It is non-seasonal and provides a continuous supply of nuts practically month after month. This is quite an advantage in maintaining a processing plant in full operation throughout the year (Banzon, 1980).

Table 1

Values of energies of the various parts of the coconut palm

\begin{tabular}{|c|c|c|}
\hline \multicolumn{3}{|c|}{ Part of palm } \\
\hline Organ & Organ Component & $\begin{array}{c}\text { Heating value, } \\
\text { MJ/kg }\end{array}$ \\
\hline \multirow[t]{3}{*}{ Nut } & Oil & 37.57 \\
\hline & Husk & 16.69 \\
\hline & Shell & 23.01 \\
\hline Leaf & Petiole & 16.75 \\
\hline
\end{tabular}

\subsubsection{Energy-rich parts of the coconut palm}

The coconut palm is unique in having other components of the nut that are potentially large energy resources, on a sustained yield basis. These are the oil from the kernel, the husk, the shell and the leaf. The coconut trunk is not considered here being harvestable only once and only after several decades. Table 1 shows the computed heating values of the various parts of the coconut palm based on the study of Banzon (1984).

\subsubsection{The coconut leaf}

One of the largest leaves of the plant world is that of the coconut. It averages $6.1 \mathrm{~m}(20 \mathrm{ft})$ long and weighs $2.65 \mathrm{~kg}$ air-dry (Zuniga et al., 1965). The average number of fallen leaves/hectare is reported at $2507 /$ year. Ninety one per cent of the leaf is the petiole which is often used as fuel for cooking in the villages. The leaf blade constitutes $7 \%$, and the midribs, $2 \%$ of the leaf. In one leaf, the petiole (10\% moisture) will weigh $2.17 \mathrm{~kg}$ dry. A study conducted by Banzon (1980) considered only the petiole to assess the fuel potential of the coconut leaf. Banzon reported that 376.9 million trees (Anon, 1978) each producing at least 12 leaves a year or a total of $45 \times 10^{8}$ leaves with a total weight of $4000 \mathrm{kcal} / \mathrm{kg}(16.7 \mathrm{MJ} / \mathrm{kg})$ makes the energy available from the coconut petiole equal to $39 \mathrm{x}$ $10^{12} \mathrm{kcal}$. For 12 million nuts excluding the oil, the energy potential from shell and husk were reported to be $11.88 \times 10^{12}$ and $19.20 \times 10^{12} \mathrm{kcal}$ respectively, or a total of $70 \times 10^{12} \mathrm{kcal}$ equivalent to 8.6 billion liters of gasoline. About a fraction of this energy is already being used for many purposes like drying of copra, cooking fuel, production of shell charcoal etc.

\section{Materials and Methods}

\subsection{The Torrefaction Reactor}

The torrefaction batch reactor was developed and fabricated for the laboratory scale. The reactor which is of rotary drum type (capable of approximately 200 to $500 \mathrm{~g}$ per batch, depending on material) is made of stainless steel. It consists of (1) an air locked feeder cover where the feedstock is fed; (2) the heating chamber where torrefaction process of the biomass takes place; (3) rotor blades that allows uniform heating of the biomass; (4) the thermometer that displays the temperature in the heating chamber; and (5) a tachometer that measures the rotation speed of the shaft (See Fig. 2).

\subsection{The Torrefaction Experiment}

Dried coconut leaves were torrefied using the labscale torrefaction unit. Figure 2 shows the experimental set-up of the torrefaction experiment. Four torrefied samples were prepared with different torrefaction 
temperatures and different feedstock conditions as indicated in Table 2. Torrefaction temperatures were selected based on the thermal behaviour of the dried coconut leaves.

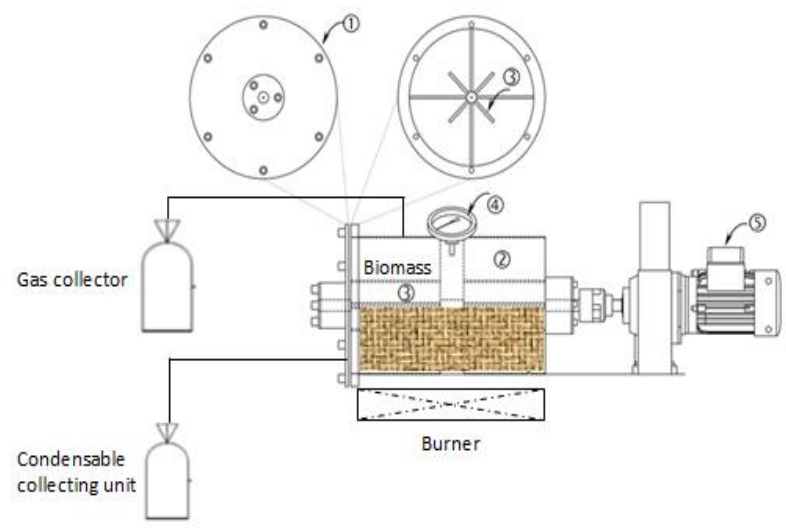

Fig. 2 The experimental set-up for torrefaction process

The reactor was heated at the rotating speed of the shaft of about $23 \mathrm{rpm}$. When the desired reaction condition was reached, the set-up was allowed to cool; the solid product or the torrefied sample (TS) was weighed. TS2 was held for 60 mins. after desired condition was reached before it was weighed. The condensate was collected throughout the process by connecting the condensate collecting unit to a condenser. The volume and weight of the condensate were measured. The collected gas and the condensate were disposed properly. Some physical and combustion properties of the torrefied biomass were examined.

Tabel 2

Feedstock initial condition and torrefaction temperature

\begin{tabular}{cccc}
$\begin{array}{c}\text { Coconut } \\
\text { leaves sample }\end{array}$ & Length & drying period & $\begin{array}{c}\text { Torrefaction } \\
\text { Temp. }\left({ }^{\circ} \mathbf{C}\right), \\
\text { holding time, min }\end{array}$ \\
\hline Raw 1 & $2 \mathrm{~mm}$ & 3 days & 245 \\
Raw 2 & $1 \mathrm{~cm}$ & 3 days & 295 \\
Raw 3 & $2 \mathrm{~mm}$ & $\begin{array}{c}\text { Air-dried for 3 days } \\
\text { then oven-dried for } \\
2 \text { hours at } 105^{\circ} \mathrm{C}\end{array}$ & $245,60 \mathrm{~min}$ \\
Raw 4 & $1 \mathrm{~cm}$ & 3 weeks & 295 \\
\hline
\end{tabular}

\subsection{Thermo gravimetric Analysis (TGA)}

The thermal behaviors of dried coconut leave (about $5.769 \mathrm{mg}$ milled using a Thomas Willey mill) were investigated at the Polymer Materials Laboratory at the Institute of Chemistry, College of Science, University of the Philippines, Diliman, Quezon City using a TGA Q50 (TA Instrument). The heating program consisted on a 5 min hold at $30^{\circ} \mathrm{C}$, ramp up to $800^{\circ} \mathrm{C}$ at a heating rate of $10^{\circ} \mathrm{C} / \mathrm{min}$, and then the weight difference was recorded as a function of temperature profile. Nitrogen was used as a purging gas at a flow rate of $50 \mathrm{ml} / \mathrm{min}$.

\subsection{Calorific Values (CV)}

The calorimetric experiments were performed using the dried coconut leaves cut into small pieces and finely ground torrefied biomass. About $1 \mathrm{~g}$ size sample was placed in a nickel crucible introduced into a Parr 1356 Oxygen Combustion Bomb Calorimeter at the Polymer Laboratory at the Institute of Chemistry, College of Science, U.P. Diliman. The experiments were performed at $25^{\circ} \mathrm{C}$. The bomb was filled with oxygen at a filling pressure of $30 \mathrm{~atm}$. The calorimeter was placed in an isothermal-jacket with an air-gap separation of $10 \mathrm{~mm}$ between all surfaces. The calorimeter was filled with two liters of de-ionized water. The fuel was ignited through external electric connections. Temperature of this water was measured to $10^{-4}{ }^{\circ} \mathrm{C}$ at intervals of $10 \mathrm{~s}$ at the start of ignition to calculate the heating value of each sample.

\subsection{Proximate Analysis}

Samples of the feedstock and the solid product or torrefied biomass were analysed at the Analytical Services Laboratory at the Institute of Chemistry, U.P. Diliman, Q. C. for moisture content using a micro thermo gravimetric analyser according to Method 925.45 B "Official Methods of Analysis of AOAC International (17 $7^{\text {th }}$ edition Revision 1 ) and ash content according to Method 92303 Ibid.

\subsection{Hydrophobicity Test}

Hydrophobicity test for the torrefied biomass was conducted according to STRI Guide 1, 92/1 with the following adaptations. A spray bottle which can produce a fine mist was filled with tap water. The water shall not contain any chemicals, as detergents, solvents. From a distance of $25 \pm 10 \mathrm{~cm}$, the torrefied sample was sprayed with water 1-2 times per second. The spraying shall continue for 20-30 seconds. The judgement of the hydrophobicity classification shall be performed within 10 seconds after the spraying has been finished. The criteria for classification were a) water repellent and b) easily wetted.

\section{Result and Discussion}

Torrefaction is usually performed in inert atmosphere at temperature below $300^{\circ} \mathrm{C}$ that aims to remove mostly the major hemicellulose contents from biomass structure (Ramiah 1970, Worasuwannarak et al. 2007).

\subsection{TGA}

The thermogravimetry profile of dried coconut leaves in Figure 3 shows an onset temperature of 
$245.05^{\circ} \mathrm{C}$ that denotes the temperature at which weight loss begins.

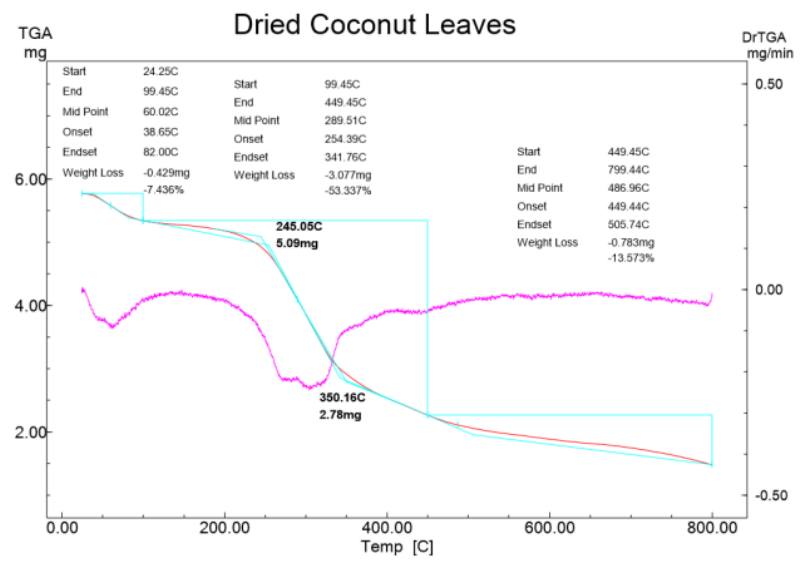

Fig. 3 Thermogravimetry profile of dried coconut leaves

Starting from $5.679 \mathrm{~g}$, a weight loss of $7.436 \%$ was observed. After which the weight drastically falls down until a temperature of $350.16^{\circ} \mathrm{C}$ is reached when a weight loss of $53.33 \%$ of its weight was recorded. This is called the first derivative peak temperature, also known as the inflection point. This indicates the point of greatest rate of change on the weight loss curve. It was reported that the higher the cellulosic content of the dried coconut leaves, the higher was the thermal degradation rate and the initial degradation temperature.

\subsection{Calorific Value, Proximate Analysis}

The calorific value obtained in a bomb calorimeter test represents the gross heat of combustion for the sample. This is the heat produced when the sample burns, plus the heat given up when the newly formed water vapor condenses and cools to the temperature of the bomb. A CV of $17.95 \mathrm{MJ} / \mathrm{kg}$ was recorded for dried coconut leaves that were air-dried for 3 days while a calorific value reading of $19.3 \mathrm{MJ} / \mathrm{kg}$ for those that were air dried for three (3) weeks (See Table 3).

Table 3

Proximate Analysis and Calorific Values of dried coconut leaves

\begin{tabular}{|c|c|c|c|}
\hline $\begin{array}{c}\text { Coconut leaves } \\
\text { drying period }\end{array}$ & $\begin{array}{c}\text { Calorific } \\
\text { Value, MJ/kg }\end{array}$ & \% Moisture & \%Ash \\
\hline 3 days & 17.95 & 10.49 & 6.17 \\
\hline 3 weeks & 19.13 & 9.32 & 6.14 \\
\hline
\end{tabular}

A higher $\mathrm{CV}$ has been observed for coconut leaves subjected to longer drying period. This is attributed to the low water content of the feedstock that increases the heating value of the biomass.

The biomass low heating values are due to low fixed carbon content of about $45 \%$ and relatively high moisture content, typically about 50\% (Crocker, M.;
Andrews 2010). Torrefaction significantly improved the heating values of the biomass (Table 4). Improvement of heating value is due to increased fixed carbon. The fixed carbon content of torrefied biomass is high (25$40 \%$ depending on reaction conditions) (Bergman and Kiel 2005, Medic et al. 2012, Park and Jang 2012). The combustion property also improved; torrefied biomass burns longer due to larger percentage of fixed carbon (Bridgeman et al. 2008). Torrefaction reduces the $\mathrm{O} / \mathrm{C}$ ratio and this makes the biomass better suited for gasification (Medic et al. 2012). Gasification also produces less smoke during combustion since smoke causing volatiles are driven off during torrefaction (Tumuluru et al. 2012, Patel et al. 2011).

Table 4

Proximate Analysis and Calorific Values of dried coconut leaves

\begin{tabular}{|cccc} 
Torrefied Sample & CV, MJ/kg & \% Moisture & \%Ash \\
\hline TS 1 & 22.71 & 3.83 & 8.50 \\
TS 2 & 27.08 & 3.71 & 9.37 \\
TS 3 & 24.82 & 3.65 & 8.36 \\
TS 4 & 27.78 & 3.48 & 10.45 \\
\hline
\end{tabular}

\subsection{Hydrophobicity and Storage}

The equilibrium moisture percentage dropped to $3.5-3.8 \%$ (See Table 4). This is due to the removal of $\mathrm{OH}^{-}$groups and formation of unsaturated structures during torrefaction process that renders the biomass hydrophobic. Hydrophobicity tests confirmed that all torrefied coconut leaves did not absorb moisture. The low moisture content renders torrefied coconut leaves resistant to biological degradation and can therefore be transported and stored for long periods.

Biomass can be torrefied and pelletized in decentralized locations and stored for long period without an impact on its quality (Arias et al. 2008). Such pre-treatment also improves the economics of transportation and handling biomass.

\subsection{Torrefaction Products}

Key torrefaction reaction products (of which the solid is of main interest) can be classified according to their state at atmospheric pressure and room temperature (Prins et al. 2006). These include solids (in the form of char, original sugar structures and ash) and all the volatile compounds released during the process. The volatiles consist of condensables or liquids (mainly water, organics and lipids) and non-condensables or the permanently gaseous fraction (mainly $\mathrm{CO}$ and $\mathrm{CO}_{2}$ ) (Kiel et al. 2012, Tumuluru et al. 2010, Chen et al. 2012).

\subsubsection{Solid Product}

Using $200 \mathrm{~g}$ of dried coconut leaves for each run, there was an overall trend toward a decrease in yield of 
solid products or torrefied biomass, and increase in yield of condensables products as both temperature and reaction time increased (Table 5). Loss of solids was pronounced between 245 and $295^{\circ} \mathrm{C}$ regardless of moisture content of samples. This was likely due to higher reactivity or more extensive devolatilization and carbonization of hemicellulose fraction above $245^{\circ} \mathrm{C}$. Along with degradation of hemicellulose, initial reactions of cellulose decomposition might occur in this temperature regime, as proposed by other researchers (Koukious et al. 1982). Particle size did not have a significant effect on the torrefaction of dried coconut leaves in the $2-10 \mathrm{~mm}$ range. Residence time did not considerably affect the product yield. There is only $5 \%$ in average weight loss when 60 min residence time was employed. It was observed that torrefaction time was less significant than temperature.

\subsubsection{Condensables}

The same trend was observed for the yield of condensables. Table 5 shows the yield of condensables volatile products was highest for TS2 at $40.95 \mathrm{~g}$ during the torrefaction at $295^{\circ} \mathrm{C}$, while the yield was lowest for TS3 at $13.97 \mathrm{~g}$ that was torrefied at $245^{\circ} \mathrm{C}$ with $60 \mathrm{~min}$ residence time. The yield of condensables increased with torrefaction temperature. A decreasing tendency of condensables with increase in holding time could be seen.

\subsubsection{Permanent Gases}

Permanent gas released in the process was mainly composed of carbon dioxide and carbon monoxide, with traces of hydrogen and methane present only at $300^{\circ} \mathrm{C}$.

Table 5

Product Yield and Composition

\begin{tabular}{ccccc}
$\begin{array}{c}\text { Torrefied } \\
\text { Sample }\end{array}$ & $\begin{array}{c}\text { Torrefaction } \\
\text { Temp, holding } \\
\text { time }\end{array}$ & $\begin{array}{c}\text { wt. of } \\
\text { torrefied } \\
\text { sample, }\end{array}$ & $\begin{array}{c}\text { \%wt. } \\
\text { loss }\end{array}$ & $\begin{array}{c}\text { wt. of } \\
\text { condensab } \\
\text { les, g }\end{array}$ \\
\hline TS 1 & $245^{\circ} \mathrm{C}$ & 141.05 & 29.49 & 26.55 \\
TS 2 & $295^{\circ} \mathrm{C}$ & 122.24 & 38.90 & 40.95 \\
TS 3 & $245^{\circ} \mathrm{C}, 60 \mathrm{~min}$ & 150.98 & 24.54 & 13.97 \\
TS 4 & $295^{\circ} \mathrm{C}$ & 123.93 & 38.05 & 33.50 \\
\hline
\end{tabular}

\subsection{Color}

The dried coconut leaves underwent a change in color during the torrefaction process that corresponds to changes in both chemical and physical characteristics. Figure 4 shows the color of raw biomass was altered to different extents, ranging from shades slightly darker than the original material to black, depending mainly on the treatment temperature.

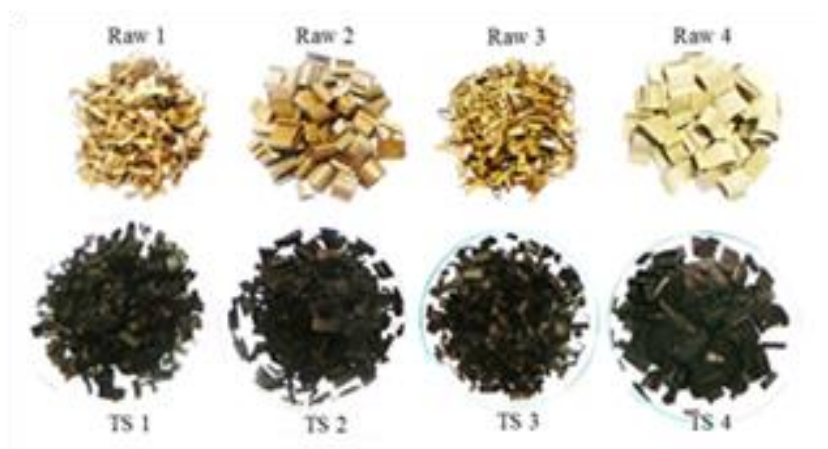

Fig. 4 Physical appearances of raw and torrefied biomass

\subsection{Homogeneity}

Torrefied biomass can be produced from a wide variety of raw biomass feed stocks while yielding similar product properties. Most woody and herbaceous biomass consists of three main polymeric structures: cellulose, hemicellulose and lignin. Together these are called lignocellulose. Torrefaction primarily drives moisture and oxygen-rich and hydrogen-rich functional groups from these structures, resulting in similar char-like structures in all three cases. This phenomenon generates a homogeneous particle mixing.

Torrefaction of coconut leaves improved the biomass homogeneity, produced a solid uniform product and retained the shape and dimensions of the raw biomass. The torrefied leaves has a lower bulk density. It contains $40-80 \%$ of the original mass. This is due to devolatilization and drying since the torrefaction temperature range is relatively wide $\left(200-300^{\circ} \mathrm{C}\right)$. Moreover, solid product appeared as friable to the touch compared to the raw biomass.

\subsection{Grindability}

Improved grindability of torrefied biomass was observed to be dependent on the torrefaction temperature, residence time and the drying period of the feedstock. This observation was confirmed when the torrefied samples were ground manually using a mortar and pestle. It was noted that TS4 has the most improved grindability compared to the other three due to its high treatment temperature of $295^{\circ} \mathrm{C}$ and longer drying period of the feedstock. It was also observed that among the torrefied samples, TS4 easily disintegrated when handled.

It was noted that although TS1 and TS3 have the same treatment temperature at $245^{\circ} \mathrm{C}$, but an improved grindability of TS3 was noticed. This is attributed to the 

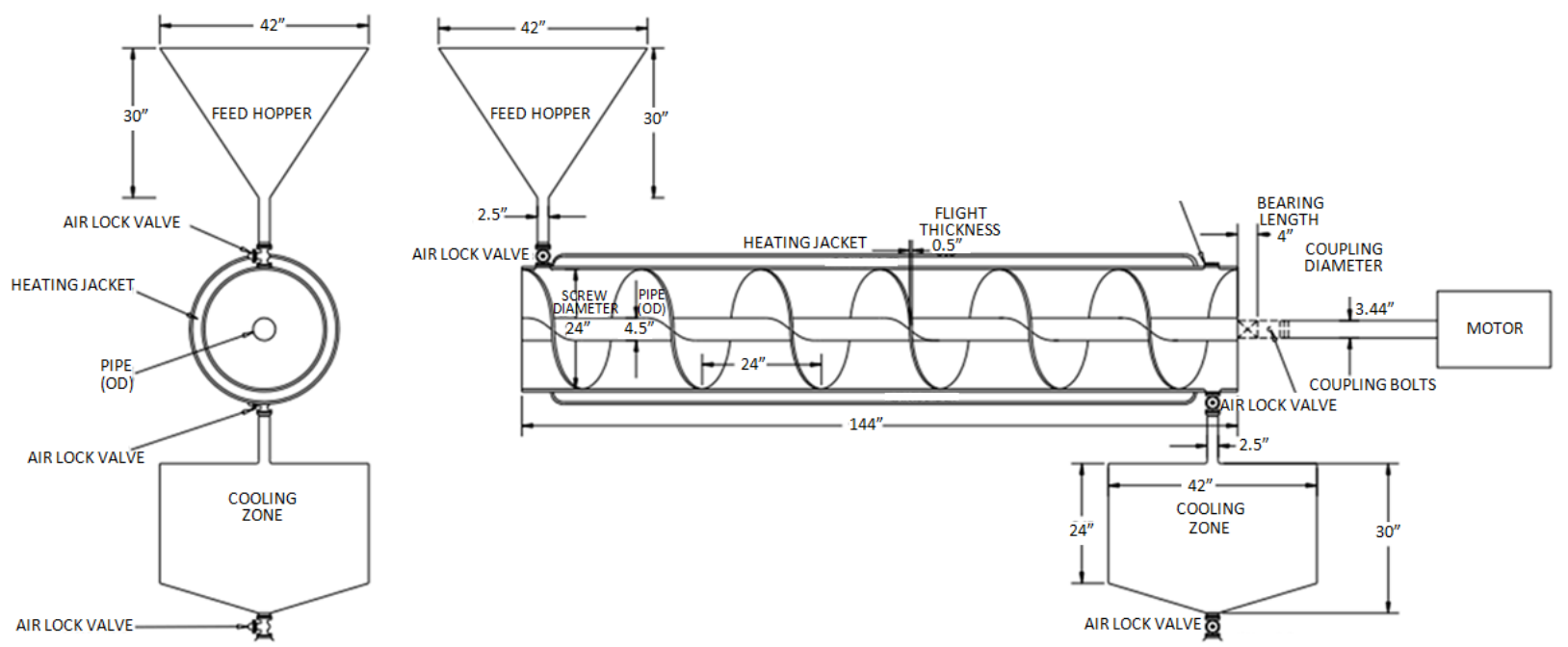

Fig. 5 The Proposed Torrefaction Reactor Design

longer holding time that TS3 spent in the torrefaction reactor. It was observed that there was little improvement in biomass grindability at torrefaction temperature of $245^{\circ} \mathrm{C}$.

Torrefied biomass requires less electricity to grind compared to dried coconut leaves. On grinding, the particle size distributions, sphericity, and particle surface areas become similar to coal (Phanphanich and Mani 2011). The torrefied biomass also results in improved chemical composition making it more suitable for fuel applications (Tumuluru et al. 2011).

\section{Conclusion}

Torrefaction of dried coconut leaves significantly improved the heating value compared to that of the untreated biomass. Proximate compositions of the torrefied biomass also improved and were comparable to coal. Physical characteristics and combustion characteristics of torrefied biomass were superior compared to that of untorrefied biomass making it more suitable for fuel applications in the indirect drying of coconut meat in the farm-level to produce copra.

\section{Recommendations}

Torrefaction has the potential to become an important biomass pre-treatment technology and improve the biomass to a high quality solid fuel with good characteristics in energy density, homogeneity, grindability and hydrophobic behaviour. Characteristics such as pelletization, biological degradation and dust forming of the torrefied biomass need more attention. Analyses for physical and fuel properties of the torrefied biomass are recommended such as grindability test, solid, gas, and liquid yield analyses, proximate and ultimate analyses, bulk density, particle density, particle size distribution, chemical composition and energy density. And, further research on kinetics is recommended to get the data needed for reactor design in the large scale. Figure 5 shows the proposed torrefaction reactor design in the large scale. A heating jacket that uses the heat generated from the pyrolysis of coconut shell, a coconut farm waste at the farm-level, will torrefy the biomass.

\section{References}

Anon. 1978 Leucaena - Promising Forage and Tree Crop for the Tropics. Report on a study conducted jointly by the Philippine Council for Agriculture and Resources Research and the United States National Academy of Sciences. U.S. National Academy of Sciences, Washington, D.C.

Antal, M.J., M. Gronli. (2003). The art, science and technology of charcoal production. Industrial and Engineering Chemistry Research, 42, 1619-1640.

Bell, M.J., F. Worrall. (2011). Charcoal addition to soils in NE England: A carbon sink with environmental co-benefits? Sci. Total Environ. 409, 1704-1714.

Almeida, G., Brito, J.O., Perre, P. (2010). Alterations in energy properties of eucalyptus wood and bark subjected to torrefaction: the potential of mass loss as a synthetic indicator. Bioresource Technology , 101(24),9778-9784.

Arias, B., Pevida, C., Fermoso, J., Plaza M.G., Rubiera, F., Pis, J.J. (2008). Influence of torrefaction on the grindability and reactivity of woody biomass. Fuel Proc Technol, 89(2),169-75.

Balat, M., Balat, M., Kirtay, E., Balat, H. (2009). Main routes for the thermo-conversion of biomass into fuels and chemicals. Part 1: Pyrolysis systems. Energy Convers Manage, 50,3147-57.

Banzon, J.A. (1980). The coconut as a renewable energy. Philipp J. of Coconut studies. 5(1):31-36

Banzon, J.A. (1984). Harvestable energy from the coconut palm. Energy in Agriculture, 3,337-344.

Basu, P. (2010). Biomass Gasification and Pyrolysis: Practical Design. Academic Press: Burlington, MA, 2010.

Beekes, M., Cremers, M. (2012). Realising a co-firing dream. Power Eng Int, 20(8), 64-70. 
Ben, H., Ragauskas, A.J. (2012). Torrefaction of Loblolly pine. Green Chem ,14,72-76.

Bergman, P., Kiel, J. (2005). Torrefaction for biomass upgrading; 14th European Biomass Conference \& Exhibition, Paris, France, 17-21 October 2005

Bridgeman T.G., Jones, J.M., Shield, I., Williams, P.T. (2008). Torrefaction of reed canary grass, wheat straw and willow to enhance solid fuel qualities and combustion properties. Fuel, 87, 844-856.

Bridgewater, A.V. (2012). Review of fast pyrolysis of biomass and product upgrading. Biomass Bioenergy,38,68-94.

Brožek, M., Nováková A., Kolářová, M. (2012). Quality evaluation of briquettes made from wood waste, Research Agriculture Engineering, 58(1), 30-35.

Budarin, V.L., Milkowski, K.J., Shuttleworth, P., Lanigan, B., Clark, J.H., Macquarrie, D.J., Wilson, A. (2011) Microwave torrefaction of biomass, US Patent US 2011/021979 A1, 07.01.2010.

Chen, W.H., Lu, K.M., Tsai, C.M. (2012). An experimental analysis on property and structure variations of agricultural wastes undergoing torrefaction. Appl Energy, 100,318-25.

Ciolkosz, D., Wallace, R. (2011). A review of torrefaction for bioenergy feedstock production. Biofuel Bioprod Bior, 5(3),31729.

Crocker, M.; Andrews, R. (2010). The Rationale for Biofuels. In Thermochemical Conversion of Biomass to Liquid Fuels and Chemicals, pp. 1-25. Crocker, M., Ed. RSC Publishing: Cambridge, 2010.

Davis, S.C., Anderson-Teixeira, K.J., De Lucia, E.H. (2009). Life-cycle analysis and the ecology of biofuels. Trends Plant Sci ,14,140-6.

Demirbas, A. (2001). Biomass resource facilities and biomass conversion processing for fuels and chemicals. Energy Conv Manage, 42,1357-78.

Dhungana, A. (2011). Torrefaction of biomass. MSc thesis. Halifax. Nova Scotia: Dalhousie University, p.151.

Fisher, T., Hajaligol, M., Waymack, B., Kellog, D. (2002). Pyrolysis behaviour and kinetics of biomass derived materials. J Anal Appl Pyrol, 62,331-49.

Herman, W.A. (2006). Quantifying global exergy resources. Energy 31(12),1685-702

Karunanithy, C., Wang Y., Muthukumarappan K., Pugalendhi S. (2012). Physiochemical characterization of briquettes made from different feedstock's, Hindawi Publishing Corporation Biotechnology Research International, Article ID 165202, 12 pages.

Kiel, J., Zwart, R., Verhoeff, F. (2012). Torrefaction by ECN. In: Presentation to the SECTOR/IEA bioenergy torrefaction workshop, $20^{\text {th }}$ European biomass conference and exhibition, June $21^{\text {st }}, 2012$, Milan, Italy.

Kim, Y., Lee, S., Lee, H., Lee, J. (2012). Physical and chemical characteristics of products from the torrefaction of yellow poplar (Liriodendron tulipifera). Bioresource Technol, 116,120125.

Kleinschmidt, C.P. (2011). Overview of international developments in torrefaction. In: Paper presented at the IEA bioenergy task 32 and task 40 workshop on "development of torrefaction technologies and impacts on global bioenergy use and international bioenergy trade". 28 $8^{\text {th }}$ of January 2011. Graz 2011.

Koukious E. G., Mavrokoukoulakis J., Abatzoglou N. Energy densification of biomass. Proceedings of 1st. National Conference on Soft Energy Forms;1982; Thessaloniki, Greece.

Li H., Liu X., Legros L., Bi X.T., Lim C.J., Sokhansanj S. (2012). Torrefaction of sawdust in a fluidized bed reactor. Bioresource. Technol. 103, 453-458.

Lu, G.Q., Toyoma, T., Kim, H.J., Naruse, I., Ohtake, K. (1997). Fundamental study on combustion characteristics of biobriquette. Kagaku Ronbun ,23,404-12.

Lu, K., Lee, W., Chen, W., Liu, S., Lin, T. (2012). Torrefaction and low temperature carbonization of oil palm fiber and eucalyptus in nitrogen and air atmospheres. Bioresource Technol ,123,98105
Medic, D., Darr, M., Shah, A., Potter, B., Zimmerman, J. (2012). Effects of torrefaction process parameters on biomass feedstock upgrading. Fuel, 91,147-54.

Melin, S. (2011). TORREFIED wood-a new emerging energy carrier. In: Presentation to clean coal power coalition CCPC March 9, 2011.

Mohan D., C.U. Pittman, P.H. Steele. (2006). Pyrolysis of wood/biomass for bio-oil: A critical review. Energ. Fuel, 20, 848-889.

Park, S-, Jang, C-. (2012). Effects of pyrolysis temperature on changes in fuel characteristics of biomass char. Energy, 39,18795.

Patel, B., Gami, B., Bhimani, H. (2011). Improved fuel characteristics of cotton stalk, prosopis and sugarcane bagasse through torrefaction. Energy Sustain Dev, 15,272-5.

Phanphanich,M., Mani, S. (2011). Impact of torrefaction on the grindability and fuel characteristics of forest biomass. Bioresource Technol;102(2),1246-53.

Prins, M.J., Ptasinski, K.J., Janseen, FJJG. (2006). From coal to biomass gasification via torrefaction: comparison of thermodynamic efficiency. Energy,32(7),1248-59.

Prins, M.J., Ptasinski, K.J., Janseen, FJJG. (2006). More efficient biomass gasification via torrefaction. Energy, 31(15),3458-70.

Prins, M.J., Ptasinski, K.J., Janseen, FJJG. (2005). Energy and exergy analyses of the oxidation and gasification of carbon. Energy 30(7),982-1002.

Ramiah, M.V. (1970). Thermogravimetric and differential thermal analysis of cellulose, hemicellulose and lignin, Journal of Applied Polymer Science, 14, 1323-1337.

Ren S., Lei H., Julson J., Wnag L., Bu Q., Ruan R. (2010). Microwave Torrefaction of Corn Stover. Paper 1110765. Annual International Meeting of the ASABE, Louisville, KN, 2010.

Rousset, P, Macedo, L., Commandre, J-, Moreira, A. (2012). Biomass torrefaction under different oxygen concentrations and its effect on the composition of the solid by-product. J Anal Appl Pyrol, 96,86-91.

Rousset, P., Fernandes, K., Vale, A., Macedo, L., Benoist, A. (2013). Change in particle size distribution of torrefied biomass during cold fluidization. Energy, 51,71-7.

Schorr, C., Muinonen, M., Nurminen, F. (2012). Torrefaction of biomass. Mikkeli, Finland: Mikteck Ltd/Ventre of Expertiseprogramme; p. 55.

Tumuluru, J.S., Sokhansanj, S., Wright, C.T., Boardman, R.D. (2010). Biomass torrefaction process review and moving bed torrefaction system model development. US: Idaho National Laboratory: 2010. p. 57. INL/EXT-10-19569-1.

Tumuluru, J.S., Sokhansanj, S., Wright, C.T., Hess, J.R., Boardman, R.D. (2011). A review on biomass torrefaction process and product properties. Symposium on thermochemical conversion. In: Symposium on thermochemical conversion, Oklahoma State University, Stillwater, OK, August 2 ${ }^{\text {nd, }}$ 2011. p.15.

Tumuluru, J.S., Hess, J.R., Boardman, R.D., Wright, C.T., Westover, T.L. (2012). Formulation pretreatment, and densification options to improve biomass specifications for co-firing high percentages with coal. Ind Biotechnol, 8(3),113-32.

Ustu, A., Faaij, A.P.C., Bergman, P.C.A. (2008). Pretreatment technologies, and their effect on international bioenergy supply chain logistics. Techno-economic evaluation of torrefaction, fast pyrolysis and pelletization. Energy, 33(8),1206-23.

Van der Stelt, M.J.C., Gerhauser, H., Kiel, J.H.A., Ptasinski, K.J. (2011). Biomass upgrading by torrefaction for the production of biofuels: A review. Biomass and Bioenergy 35, 3748-3762.

Van Essendelft, D.T., Zhou, X, Kang, B.S.-J. (2013). Grindability determination of torrefied biomass materials using the hybrid work index. Fuel, 105,103-11.

Wannapeera, J., Worasuwannarak, N. (2012). Upgrading of woody biomass by torefaction under pressure. J Anal Appl Pyrol, 96,173-80.

Worasuwannarak, N., Sonobe, T., Tanthapanichakoon, W. (2007). Pyrolysis behaviors of rice straw, rice husk, and corncob by TGMS technique, Journal of Analytical and Applied Pyrolysis, 78, 265-271. 
Yaman, S., Sahan, M., Haykiri-Acma, H., Sesen, K., Kücükbayrak, S. (2000). Production of fuel briquettes from olive refuse and paper mill waste. Fuel Process Technol ,68,23-31.

Yaman, S., Sahan, M., Haykiri-Acma, H., Sesen, K., Kücükbayrak, S. (2001). Fuel briquettes from biomass-lignite blends. Fuel Process Technol, 72,1-8.

Yan, W., Acharjee, T.C., Coronella, C.J. Vásquez, V.R. (2009). Thermal pretreatment of lignocellulosic biomass. Environ Prog Sustain Energy, 28(3),435-40.
Yan, W., Hastings, J., Acharjee, T., Coronella, C. and Vasquez, V. (2010). Mass and energy balances of wet torrefaction of lignocellulosic biomass. Energy \& Fuel, 24, 4738-4742.

Zhang, Q., Chang J., Wand, T., Xu, Y. (2007). Review of biomass pyrolysis oil properties and upgrading research. Energy Convers Manage, 48, 87-92.

Zuniga, L.C., Pampolina, C. and Pampolina, E., (1965). Number of dried leaves falling per day, per hectare in a coconut plantation. Rep. .93. National Science Development Board, Philippines. 